\title{
ECOLOGICAL STUDY OF VIRAL HEPATITIS IN BRAZIL: A GEOGRAPHICAL AND TEMPORAL ANALYSIS
}

Clin Biomed Res. 2019;39(2):122-127

1 Faculdade de Medicina, Universidade de Passo Fundo (UPF). Passo Fundo, RS, Brasil

2 Departamento de Hepatologia, Hospital São Vicente de Paulo (HSVP). Passo Fundo, RS, Brasil

3 Departamento de Cirurgia Digestiva, Hospital São Vicente de Paulo (HSVP). Passo Fundo, RS, Brasil

4 Faculdade de Medicina, Universidade Federal do Rio Grande do Sul (UFRGS). Porto Alegre, RS, Brasil

Corresponding author: Victor Antonio Kuiava victorkuiava@gmail.com Faculdade de Medicina, Universidade de Passo Fundo (UPF)

Rua Teixeira Soares, 817. 99010-080, Passo Fundo, RS, Brasil.

\section{Victor Antonio Kuiava ${ }^{1}$, Nathalia Regina Pavan¹, Eduardo Torres Grisolia ${ }^{1}$,} Lisia Hoppe ${ }^{1,2}$, Paulo Roberto Reichert ${ }^{1,3}$, Daniel Navarini ${ }^{1,3,4}$

\section{ABSTRACT}

Introduction: Viral hepatitis is a group of diseases that present high hepatotropism and are related to liver dysfunctions, having either an acute or a chronic course. Their worldwide epidemiology is diverse, with several endemic places, such as South America. The objective of this study was to analyze the epidemiology of viral hepatitis in Brazil, in order to better understand its pattern of distribution and evolution.

Method: A temporal aggregation study was conducted using the Viral Hepatitis Database of the Brazilian Ministry of Health. The serological markers used were HBsAg and anti-HCV for hepatitis B and C, respectively. Mortality data were collected from the Mortality Information System for deaths attributed to viral hepatitis. The period analyzed was from 2007 to 2016/17.

Results: The incidence was $7.88(95 \% \mathrm{Cl}, 7.30-8.45)$ for hepatitis B and 11.9 $(95 \% \mathrm{Cl}, 11.15-12.65)$ for hepatitis C. Mortality attributed to viral hepatitis was 1.61 (95\% Cl, 1.35-1.87) deaths per 100,000 people. An analysis of municipal distribution data showed several endemic areas. The Brazilian regions most affected by hepatitis $B$ virus were the northern and southern borders, Santa Catarina coast and Espírito Santo state, while hepatitis $C$ virus was mostly present in metropolitan areas such as Porto Alegre and São Paulo.

Conclusions: Viral hepatitis has a diverse geographic distribution in the Brazilian territory, with highly endemic areas. The distribution differs between hepatitis $B$ and hepatitis $\mathrm{C}$ viruses.

Keywords: Hepatitis; epidemiology; mortality; Brazil

Viral hepatitis is a group of diseases of universal distribution caused by different etiological agents ${ }^{1-3}$. They share clinical and laboratory similarities, especially hepatotropism, but with differences in epidemiology and progressive course co,2,4. $^{1,2}$.

Hepatitis B virus (HBV) infection affects around two billion people worldwide, of which 240-280 million are diagnosed with chronic hepatitis B. Among the consequences of its progression are the development of cirrhosis and hepatocellular carcinoma, which are serious hepatic lesions of great clinical concern ${ }^{3,5-8}$.

HBV transmission occurs by contact with infected blood and body fluids through reused or unsterilized medical/dental devices, tattooing and piercing, and illicit injecting drugs (when sharing needles and syringes). In addition, transmission can occur when personal objects, such as toothbrushes and nail clippers, are shared in a family context ${ }^{8-11}$.

There are several serologic markers available for HBV. HBsAg was the first marker, discovered in 1965, consisting of a viral surface antigen present in the acute phase of the disease and in its chronification. Negativity of this marker and appearance of its antibody - anti-HBs - are associated with non-chronification of the virus. Other markers used are anti-HBc IgM (early immunity) and lgG (immunological scar), HBeAg and anti-HBe. Viral load 
testing using polymerase chain reaction (PCR) is a commonly used method ${ }^{2-4}$.

Hepatitis C virus (HCV) infection affects approximately 150 million people worldwide. More than 350,000 cases per year progress to death due to the same serious liver diseases that occur with $\mathrm{HBV}^{7,12,13}$. Risk groups include those who received blood transfusions and/or blood products prior to 1992, intravenous drug users, people with tattoos and piercings, HIV carriers, transplanted, hemodialyzed or hemophiliac patients, the incarcerated population and those who are sexually promiscuous $2,10,14,15$.

The serological marker for HCV screening is total anti-HCV. This enzymatic marker commonly used in enzyme-linked immunosorbent assay (ELISA) is associated with false-positive results; therefore, when a result is positive, viral load testing with PCR must be performed to confirm the infection. However, due to financial limitations, anti-HCV is the marker of choice when screening patients for blood donation and organ transplantation ${ }^{16}$.

The control of endemic-epidemic diseases remains a major challenge in the Brazilian setting. Socioeconomic heterogeneity, irregular distribution of health services, and unequal incorporation of advanced technology for diagnosis and treatment of diseases are important issues to be considered in the evaluation of the endemic-epidemic process of viral hepatitis ${ }^{17}$. Therefore, epidemiological studies are essential for creating public strategies to combat and prevent the diseases affecting the population, especially if they are concentrated in a given region ${ }^{18}$.

Thus, this study aimed to analyze Brazilian data on the epidemiology of HBV and HCV infections in different regions, based on data from 2007 to 2016/17, in addition to correlating incidence with mortality rates. Individual studies addressing each region could provide more information about regional settings and allow for specific actions implemented locally.

\section{METHOD}

\section{Design, Population, Sample}

A temporal aggregation study was retrospectively conducted using an exploratory and quantitative documentary approach. Data were obtained from the Brazilian Ministry of Health Notification Information System (SINAN) and Mortality Information System (SIM), both available from the DATASUS Health Information System ${ }^{19}$. Demographic data for each year, age group and sex were obtained through the Brazilian Institute of Geography and Statistics (IBGE) ${ }^{20}$.

The variables observed were the reactive serological results for HBsAg and total anti-HCV in the period of 2007 to 2017 . Mortality consisted of the total number of confirmed deaths due to viral hepatitis (ICD 10: B15-B19), both in its acute and chronic forms, for the period of 2007 to 2016 . The data collected were analyzed as divided by the 27 Brazilian states and the Federal District - a division recommended by IBGE. For a comprehensive analysis, the five administrative regions of Brazil - namely South, Southeast, Midwest, North and Northeast - were also studied. The sample was divided into years of death, sex and age (0-19, 20-39, 40-59, 60-79, $\geq 80$ years). For mortality and incidence rates, data were presented in calculations for every 100,000 women or men.

The municipal distribution graphs of serum incidence of HBsAg and anti-HCV were based on SINAN data for each municipality and on the correlation with municipal areas (called "polygons") available from IBGE. Tableau software, version 10.5, was used to create the graphs.

SIM and SINAN consist of Brazilian Ministry of Health open access databases. Patient data are unidentified, and their purpose is to provide a national epidemiological profile. Therefore, these are official government data.

\section{Statistical Analysis}

The data were treated statistically and analyzed quantitatively in Microsoft Excel 2010 (Microsoft Corp., USA) and Gran Graphic Prisma, version 6. For different years, statistical comparisons were performed using Student's t-test for parametric variables and Mann-Whitney $U$ test for non-parametric variables. The data were also treated descriptively. The results are shown in graphs and tables for better interpretation. Significant values were considered when $\mathrm{p} \leq 0.05$.

\section{RESULTS}

In the study period, 154,542 serological tests were positive for HBV and 233,449 for $\mathrm{HCV}$, while 28,293 deaths were attributed to viral hepatitis in Brazil. When the populations were correlated, the rates were $7.88(95 \% \mathrm{Cl}, 7.30-8.45)$ for $\mathrm{HBV}, 11.9(95 \% \mathrm{Cl}$, 11.15-12.65) for HCV and $1.61(95 \% \mathrm{Cl}, 1.35-1.87)$ deaths per 100,000 people (Table 1 ).

In the male population, the age group most affected by HBV was $40-59$ years (42\%), while in the female population it was $20-39$ years $(53 \%)$. For HCV, the most affected age group was $40-59$ years (54\%). The peak mortality was $40-59$ years of age (43\%) due to liver dysfunctions.

The evolution pattern of these infections from 2007 to 2017 was analyzed (Figure 1). There was a $64 \%$ decrease $(p=0.001)$ in the serum incidence of HBsAg in both male and female populations of 
Table 1: Serum incidence of HBsAg and anti-HCV and mortality rate attributed to viral hepatitis per federal unit.

\begin{tabular}{|c|c|c|c|c|c|c|}
\hline \multirow{2}{*}{ Federal units } & \multicolumn{2}{|c|}{ Hepatitis $B$ virus } & \multicolumn{2}{|c|}{ Hepatitis C virus } & \multicolumn{2}{|c|}{ Mortality } \\
\hline & Incidence & $95 \% \mathrm{Cl}$ & Incidence & $95 \% \mathrm{Cl}$ & Incidence & $95 \% \mathrm{Cl}$ \\
\hline Rio Grande do Sul & 11.06 & $11.68-14.13$ & 67.37 & $63.08-71.66$ & 3.81 & $3.19-4.43$ \\
\hline Santa Catarina & 23.94 & $22.01-25.87$ & 17.13 & $15.97-18.28$ & 1.53 & $1.27-1.78$ \\
\hline Paraná & 17.85 & $15.96-19.75$ & 11.39 & 9.8-12.98 & 1.52 & $1.27-1.77$ \\
\hline São Paulo & 7.85 & 7.32-8.38 & 17.43 & $16.32-18.54$ & 2.37 & $1.98-2.76$ \\
\hline Rio de Janeiro & 4.01 & $3.29-4.74$ & 9.58 & 7.58-11.57 & 2.41 & $2.02-2.81$ \\
\hline Minas Gerais & 4.2 & $3.74-4.65$ & 5.75 & 4.69-6.81 & 0.9 & $0.75-1.05$ \\
\hline Espírito Santo & 12.77 & $11.69-13.86$ & 5.59 & $4.77-6.42$ & 1.35 & 1.1-1.6 \\
\hline Mato Grosso do Sul & 7.25 & $5.75-8.75$ & 8.61 & 7.14-10.09 & 1.44 & $1.16-1.73$ \\
\hline Mato Grosso & 20.22 & $18.2-22.24$ & 6.65 & $5.58-7.73$ & 1.19 & $0.96-1.42$ \\
\hline Goiás & 6.1 & $5.49-6.71$ & 3.8 & $3.04-4.56$ & 1.18 & $0.98-1.38$ \\
\hline Distrito Federal & 6.96 & 5.11-8.82 & 8.9 & $6.95-10.85$ & 1.01 & $0.81-1.22$ \\
\hline Acre & 86.22 & $69.17-103.27$ & 29.33 & $19.29-39.27$ & 1.55 & $1.29-1.81$ \\
\hline Rondônia & 36.83 & $24.45-49.20$ & 8.79 & $3.75-13.83$ & 2.08 & $1.69-2.48$ \\
\hline Amazonas & 17.91 & $13.23-22.59$ & 7.11 & $4.51-9.72$ & 2.31 & $1.88-2.73$ \\
\hline Roraima & 21.3 & $18.45-24.15$ & 3.94 & $2.99-4.9$ & 1.36 & 0.9-1.81 \\
\hline Pará & 2.92 & 2.42-3.41 & 2.07 & $1.55-2.59$ & 0.75 & 0.6-0.9 \\
\hline Amapá & 4.86 & $3.92-5.81$ & 4.26 & $3.61-4.9$ & 0.59 & $0.43-0.74$ \\
\hline Tocantins & 8.04 & $7.23-8.84$ & 3.2 & $2.83-3.57$ & 0.84 & $0.63-1.05$ \\
\hline Maranhão & 3.17 & $2.58-3.76$ & 2.38 & $1.87-2.88$ & 0.94 & $0.78-1.1$ \\
\hline Piauí & 1.42 & $1.14-1.7$ & 1.26 & $0.82-1.71$ & 0.67 & $0.54-0.81$ \\
\hline Ceará & 2 & $1.87-2.13$ & 2.31 & $1.79-2.82$ & 0.47 & $0.38-0.57$ \\
\hline Rio Grande do Norte & 1.54 & 1.3-1.78 & 2.45 & $2.12-2.78$ & 0.7 & $0.56-0.83$ \\
\hline Paraíba & 2.72 & $2-3.45$ & 2.19 & $1.64-2.74$ & 0.61 & $0.48-0.74$ \\
\hline Pernambuco & 2.21 & $1.67-2.75$ & 2.75 & $2.05-3.44$ & 1.07 & $0.88-1.27$ \\
\hline Alagoas & 3.73 & $2.98-4.48$ & 2.1 & $1.66-2.54$ & 0.73 & $0.59-0.88$ \\
\hline Sergipe & 5.94 & $5.42-6.46$ & 3.19 & $2.8-3.57$ & 0.75 & $0.55-0.94$ \\
\hline Bahia & 3.32 & $2.77-3.88$ & 3.64 & $3.04-4.24$ & 0.77 & $0.63-0.9$ \\
\hline
\end{tabular}
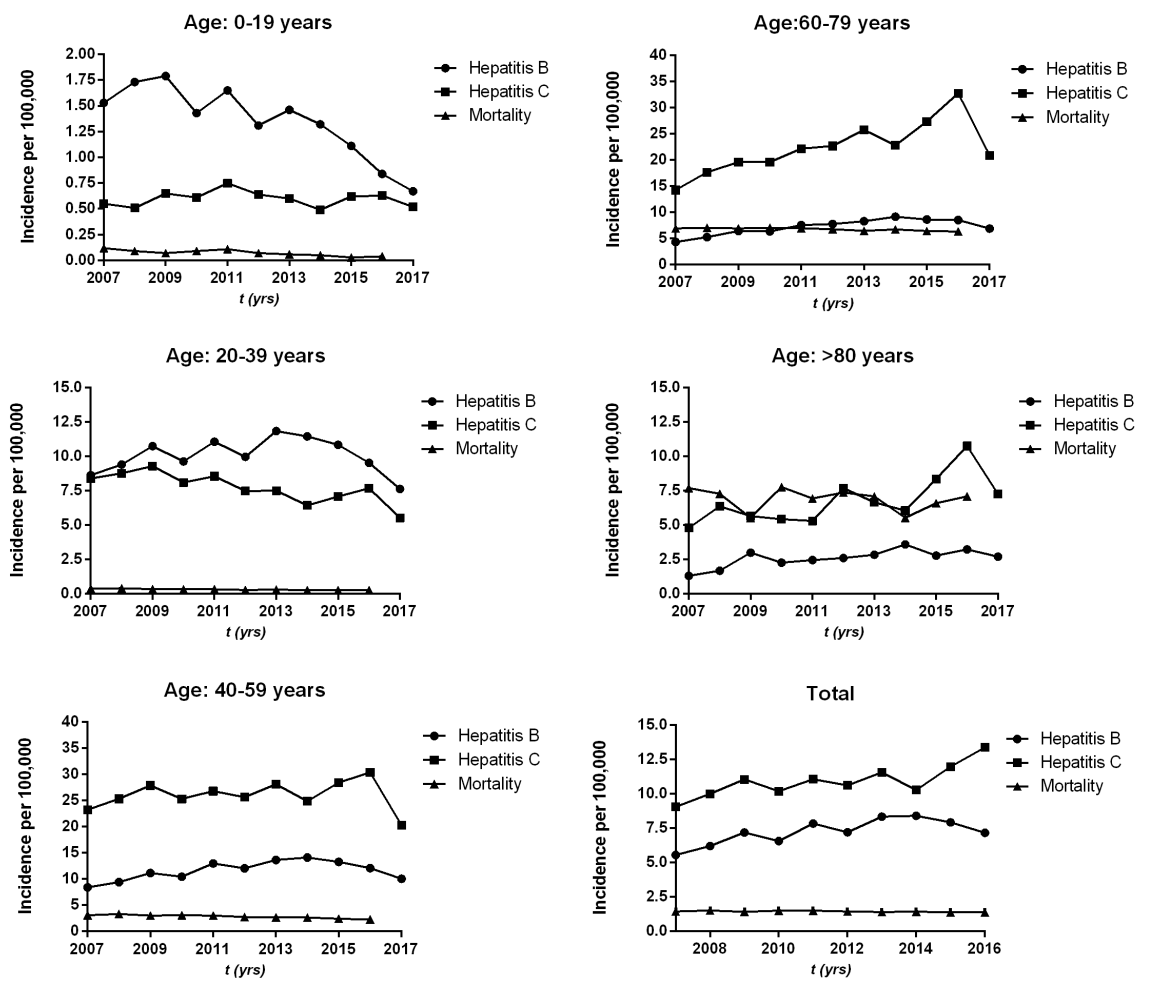

Figure 1: Demonstrating serum incidence of HBsAg and Anti-HCV and mortality rate by age group during 2007-17. 
up to 20 years of age. Serum incidence of anti-HCV increased by $47 \%(p=0.0001)$ and by $52 \%(p=0.03)$ in the populations aged $60-79$ years and above 80 years, respectively. Mortality was analyzed up to 2016 and showed a $70 \%$ reduction $(p=0.01)$ in the population aged up to 20 years.

A geographical analysis, demonstrated visually in Figure 2, illustrates the pattern of HBV endemic regions. The most affected areas were the northern border (Acre, Amazonas, Rondônia and Mato Grosso states) and the southern border (Paraná, Santa Catarina and Rio Grande do Sul states). However, it is worth mentioning that there were other endemic spots in Brazil, such as Santa Catarina northern coast and Espírito Santo state.

When the same analysis was performed for $\mathrm{HCV}$, the pattern was different from HBV (Figure 3). The most affected regions were metropolitan areas such as Porto Alegre, Santa Catarina and Paraná

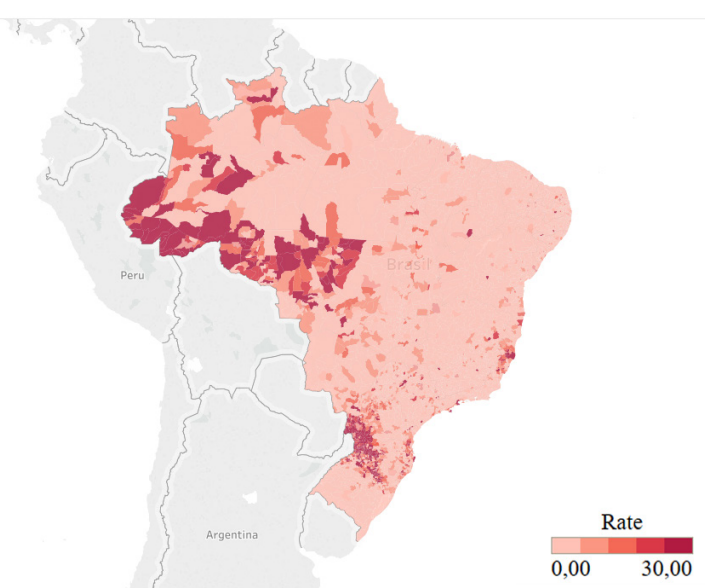

Figure 2: Municipal geographical distribution of serum HBsAg incidence between 2007-17.

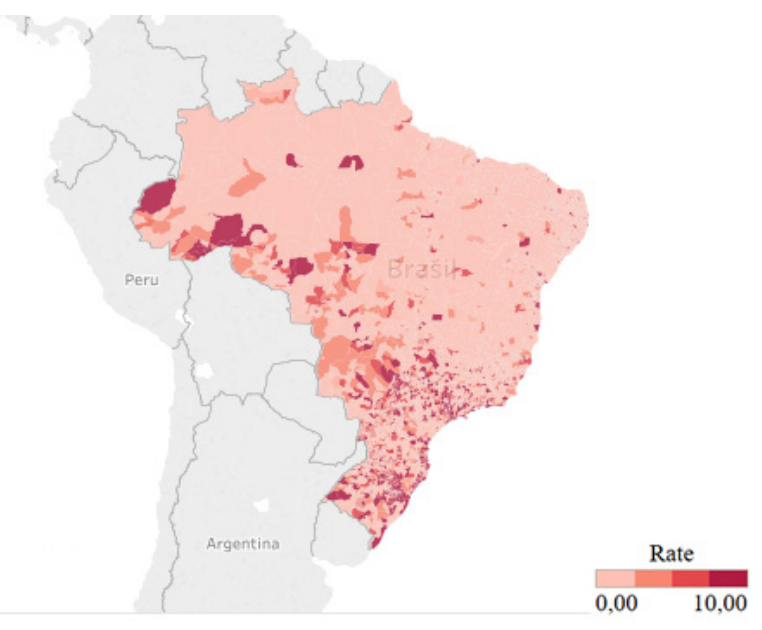

Figure 3: Municipal geographical distribution of serum anti-HCV incidence between 2007-17. coasts, São Paulo and Mato Grosso do Sul states. The border shared with Bolivia and Peru was also highly endemic.

\section{DISCUSSION}

Viral hepatitis is a serious public health problem accounting for 1.4 million deaths worldwide. In Brazil, there is a large regional variation in the prevalence of each of the etiological agents, which cross state borders. These differences are related to regional economic and population characteristics. Viral hepatitis affects a great number of individuals in the country, involving complications of its acute and chronic forms ${ }^{3,4,21}$.

The economic impact associated with hepatitis is relevant because, in endemic areas, the development of hepatocellular carcinoma and cirrhosis occurs in the young population, leading to decades of productive lives compromised. In the more advanced stages of disease progression, the costs are very high due to the consumption of health resources, such as hospitalizations, medical consultations, medications, tests and, in some cases, the need for liver transplantation ${ }^{15}$.

Transmission of HBV and HCV is mainly related to blood contamination due to injecting drug use, formerly due to contaminated blood transfusion. Sexual intercourse is still somewhat controversial in HCV transmission, with conflicting data in the literature, while in HBV transmission its role has already been proven ${ }^{6,22-24}$.

Even when the virus is transmitted, many patients may not become chronically infected, as factors such as contact age, virus type, viral load and method of transmission are important variables for chronification. The acquisition of HBV infection during childhood, mainly from maternal source, presents high chronification rates ranging from 90 to $95 \%$. However, when infection is acquired in adulthood, chronification affects only $5 \%$ of the individuals ${ }^{8,15}$. Conversely, HCV infection has high chronification rates, close to $95 \%$.

A geographical analysis of Map 1, which reveals the pattern of HBV endemic regions in the country, indicates the northern and southern borders as the most affected areas. The involvement of border areas could be explained by the fact that they are less developed and have difficulties in consolidating control measures, such as vaccination and prenatal care $^{6,23,25}$. In the northern border, Acre, Amazonas, Rondônia and Mato Grosso states have high birth rates; thus, the virus can be transmitted from mother to child, which has been frequently described in endemic areas such as East Asia and Sub-Saharan Africa ${ }^{25}$. 
There are several studies showing that the presence of family members infected with HBV is associated with a higher frequency of other infected members. The present results can be used to explain why there is a high prevalence of infected individuals in southern and northern areas, consistent with the hypothesis of virus transmission in the family environment ${ }^{9,26,27}$.

The prevalence of $\mathrm{HCV}$, as seen in Map 2, was higher in metropolitan areas such as Porto Alegre, Santa Catarina and Paraná coasts, São Paulo and Mato Grosso do Sul states. Drug injection is the most important risk factor for the acquisition of $\mathrm{HCV}$ infection in large urban centers, especially in young individuals. In addition, the high prevalence in satellite cities may be explained by the large influx of migrants ${ }^{15,24,28,29}$.

In the study period, there was a decrease in mortality due to viral hepatitis and in the number of HBV infections in the 0-19 years age group. Some possible explanations for these results are governmental measures such as HBsAg screening for pregnant women and incorporation of hepatitis $A$ and $B$ vaccines into the immunization schedule, now available to all people regardless of age. However, the increase in HCV infection found in older age groups may be due to a greater demand for serological tests ${ }^{30}$.

The data analyzed in the present study were selected from official Ministry of Health databases. All positive $\mathrm{HBsAg}$ and anti-HCV results are required to be submitted to the Brazilian government. Thus, these databases allow an analysis of the health panorama in Brazil.

\section{CONCLUSION}

Viral hepatitis in the Brazilian context has high heterogeneity, with several endemic areas for both HBV and HCV. These patterns are associated with virus characteristics and local peculiarities. There was a decrease in HBV infection and mortality rates in the young population, possibly due to the consolidation of government programs. However, the current situation is not encouraging because chronification is associated with a number of morbid conditions and a high cost to society.

\section{Acknowledgements}

The authors would like to thank the scientific support provided by the departments of Hepatology and Digestive Surgery of Hospital São Vicente de Paulo and the School of Medicine of University of Passo Fundo.

\section{Funding}

The study was funded by the authors.

\section{Conflict of Interests}

The authors declare no conflicts of interest.

\section{REFERENCE}

1. Macedo T, Silva N, Nakaoka V, Kashiwabara T. Hepatites virais: uma revisão de Literatura. Brazilian J Surg Clin Res. 2014;5:55-8.

2. Fonseca JCF. Histórico das hepatites virais. Rev Soc Bras Med Trop. 2010;43(3):32230. http://dx.doi.org/10.1590/ S0037-86822010000300022. PMid:20563505.

3. World Health Organization (WHO). Hepatitis B. Genebra; 2018. [cited 2018 Sept 20]. Available from: http:// www.who.int/en/news-room/factsheets/detail/hepatitis-b

4. Brasil. Ministério da Saúde. Secretaria de Políticas de Saúde. Departamento de Vigilância Epidemiológica.

Hepatites virais. Brasilia; 2018. [cited 2018 Sept 20]. Avaliable from: http:// bvsms.saude.gov.br/bvs/publicacoes/ hepatites virais brasil_atento 3ed.pdf
5. Petruzziello A, Marigliano S, Loquercio G, Cozzolino A, Cacciapuoti C. Global epidemiology of hepatitis $C$ virus infection: an up-date of the distribution and circulation of hepatitis $C$ virus genotypes. World J Gastroenterol. 2016;22(34):7824-40. http://dx.doi. org/10.3748/wjg.v22.i34.7824. PMid:27678366.

6. Paoli J, Wortmann AC, Klein MG, Pereira VRZB, Cirolini AM, Godoy $B A$, et al. HBV epidemiology and genetic diversity in an area of high prevalence of hepatitis $B$ in southern Brazil. Braz J Infect Dis. 2018;22(4):294304. http://dx.doi.org/10.1016/j. bjid.2018.06.006. PMid:30092176

7. Hanus JS, Ceretta LB, Simões PW, Tuon L. Incidence of hepatitis C in Brazil. Rev Soc Bras Med Trop. 2015;48(6):665-73. http://dx.doi. org/10.1590/0037-8682-0230-2015. PMid:26676490.
8. UpToDate. Hepatitis B virus: Screening and diagnosis [Internet]. Waltham; 2018 [cited 2018 April 22]. Avaliable from: www.uptodate.com

9. Lobato C, Tavares-Neto J, RiosLeite M, Trepo C, Vitvitski L, Parvaz $\mathrm{P}$, et al. Intrafamilial prevalence of hepatitis $B$ virus in Western Brazilian Amazon region: epidemiologic and biomolecular study. J Gastroenterol Hepatol. 2006;21(5):863-8. http://dx.doi.org/10.1111/j.14401746.2006.04298.x. PMid:16704537.

10. Silva CM, Peder LD, Guelere AM, Horvath JD, Silva ES, Teixeira JJV, et al. Seroprevalence of hepatitis $B$ virus (HBV) and hepatitis $C$ virus (HCV) among human immunodeficiency virus (HIV)-infected patients in an HBV endemic area in Brazil. PLoS One. 2018;13(9):1-13. http://dx.doi.org/10.1371/journal. pone.0203272. PMid:30192795. 
11. Barbosa JR, Bezerra CS, CarvalhoCosta FA, Azevedo CP, Flores GL, Colares JKB, et al. Cross-sectional study to determine the prevalence of hepatitis $B$ and $C$ virus infection in high risk groups in the northeast region of Brazil. Int J Environ Res Public Health. 2017;14(7):1-12. PMid:28714924.

12. Coelho HC, Oliveira SAN, Miguel JC, Oliveira MDLA, Figueiredo JFDC, Perdoná GC, et al. Predictive markers for hepatitis $C$ virus infection among Brazilian inmates. Rev Soc Bras Med Trop. 2009;42(4):36972. http://dx.doi.org/10.1590/ S0037-86822009000400002 PMid:19802469.

13. Cortes VF, Taveira A, Cruz HM, Reis A, Cezar JS, Silva BS, et al. Prevalence of Hepatitis $B$ and $C$ virus infection among alcoholic individuals: importance of screening and vaccination. Rev Inst Med Trop São Paulo. 2017;59(47):1-5. http://dx.doi. org/10.1590/s1678-9946201759047. PMid:28793018.

14. Facente SN, Grebe E, Burk K, Morris MD, Murphy EL, Mirzazadeh A, et al. Correction: Estimated hepatitis $C$ prevalence and key population sizes in San Francisco: A foundation for elimination. PLoS One. 2018;13(7):114. http://dx.doi.org/10.1371/journal. pone.0200866. PMid:30001389.

15. UpToDate. Epidemiology and transmission of hepatitis $C$ virus infection [Internet]. Waltham; 2018. [cited 2018 April 22]. Avaliable from: www.uptodate.com

16. Brasil. Ministério da Saúde. Hepatites Virais: características clínicas e epidemiológicas [Intenet] Brasilia; 2018. [cited 2018 Sept 20]. Available from: http://bvsms.saude.gov.br/bvs/ publicacoes/07_0044_M2.pdf

17. Luna EJA. Silva JB Jr. Doenças transmissíveis, endemias, epidemias e pandemias. In: Fundação Oswaldo Cruz. A saúde no Brasil em 2030: Prospecção estratégica do sistema de saúde brasileiro. Rio de Janeiro: Fiocruz; 2013. p. 123-176.

18. Brasil. Ministério da Saúde. Módulo de Princípios de Epidemiologia para o Controle de Enfermidades: Módulo de Princípios de Epidemiologia. Brasília; 2010. [cited 2018 April 22]. Available from: http://www.bvsms.saude.gov.br.

19. Brasil. Ministério da Saúde. DataSuS [Internet]. Brasilia: Departamento de Informática do Sistema Único de Saúde. 2018 [cited 2018 April 22]. Available from: www.datasus.saude. gov.br

20. Instituto Brasileiro de Geografia e Estatística (IBGE). Projeção da população do Brasil e das unidades da federação [Internet]. Rio de Janeiro: IBGE; 2018 [cited 2018 April 22]. Available from: www.ibge.gov.br.

21. Brasil. Ministério da Saúde. Secretaria de Vigilância em Saúde. Departamento de Vigilância Epidemiológica. Hepatites Virais: o Brasil está atento. Brasília: Ministério da Saúde; 2008.

22. Souto FJD. Distribution of hepatitis $b$ infection in Brazil: the epidemiological situation at the beginning of the 21st century. Rev Soc Bras Med Trop. 2016;49(1):11-23. http://dx.doi. org/10.1590/0037-8682-0176-2015. PMid:26689276.

23. Kretzer IF, Livramento A, Cunha J, Gonçalves S, Tosin I, Spada C, et al. Hepatitis C worldwide and in Brazil: Silent epidemic - Data on disease including incidence, transmission, prevention, and treatment. Sci World J. 2014;2014.

24. Magri MC, Ibrahim KY, Pinto WP, França FOS, Bernardo WM, Tengan FM. Prevalence of hepatitis $C$ virus in Brazil's inmate population: a systematic review. Rev Saude Publica. 2015;49(0):36. http://dx.doi.org/10.1590/ S0034-8910.2015049005886. PMid:26247383.

25. Stockdale AJ, Mitambo C, Everett D, Geretti AM, Gordon MA. Epidemiology of hepatitis B, C and D in Malawi: systematic review. BMC Infect Dis. 2018;18(1):516. http://dx.doi. org/10.1186/s12879-018-3428-7. PMid:30314448.

26. Pereira VRZB, Wolf JM, Luz CAS, Stumm GZ, Boeira TR, Galvan J, et al. Risk factors for hepatitis B transmission in south Brazil. Mem Inst Oswaldo Cruz. 2017;112(8):54450. http://dx.doi.org/10.1590/007402760170043 . PMid:28767979.

27. Perz JF, Armstrong GL, Farrington LA, Hutin YJF, Bell BP. The contributions of hepatitis $B$ virus and hepatitis $C$ virus infections to cirrhosis and primary liver cancer worldwide. J Hepatol. 2006;45(4):529-38. http:// dx.doi.org/10.1016/j.jhep.2006.05.013. PMid:16879891.

28. Parise ER. 25 years of Hepatitis $C$. Arq Gastroenterol. 2015;52(1):13. http://dx.doi.org/10.1590/ S0004-28032015000100001. PMid:26017073.

29. Pradat $P$, Virlogeux $V$, Trépo $E$. Epidemiology and elimination of HCV-Related liver disease. Viruses. 2018;10(10):545. http:// dx.doi.org/10.3390/v10100545. PMid:30301201.

30. Brasil. Ministério da Saúde. Portaria $n^{\circ}$ 1.533, 18 de Agosto de 2016. Redefine o Calendário Nacional de Vacinação, o Calendário Nacional de Vacinação dos Povos Indígenas e as Campanhas Nacionais de Vacinação, no âmbito do Programa Nacional de Imunizações (PNI), em todo o território nacional. Diário Oficial da União. 2016 Ago 18. 